\title{
Ebola: Treatment by Herbal Remedies
}

\author{
Pawanpreet Kaur *, Rupinder Sodhi, Anjoo Kamboj, Arockia Babu \\ Chandigarh College of Pharmacy, Landran, Mohali (Punjab)
}

Address for Correspondence: Pawanpreet Kaur; pb546125@gmail.com

\begin{tabular}{l} 
Received: \\
01.03.2019 \\
Accepted: \\
25.03.2019 \\
Keywords \\
Natural \\
Remedies; \\
Herbal \\
Treatment; Ebola \\
Virus. \\
\hline
\end{tabular}

Received:

Accepted:

Keywords

Natural

Remedies;

Treatment; Ebola

Virus.

\begin{abstract}
Ebola virus is the single member of the species Zaire Ebola virus, which is the type species for the genus Ebola virus, family Filoviridae, order Mononegavirales. The natural reservoir of Ebola virus is believed to be bats, particularly fruit bats, and it is primarily transmitted between humans and from animals to humans through body fluids. The Ebola virus has a high mortality rate, with a current case fatality rate estimated to be around 50\%. Mortality rates for previous outbreaks have varied from $25 \%$ to $90 \%$, and those outbreaks have been relatively short-lived (WHO, 2014) seen near the tropical rainforests of remote villages in Central and West Africa. It is spread by close contact with patients or exposure to infected biologic fluids. The virus has been found in the blood, saliva, feces, breast milk, tears, and genital secretions of infected patients. Ebola virus causes significant immune suppression and a systemic inflammatory response, leading to multi organ failure and shock. No particular anti-viral therapy has demonstrated effectiveness in Ebola virus infection. Also, no vaccine for use in humans is yet approved by the regulatory bodies. No particular anti-viral therapy has demonstrated effectiveness in Ebola virus infection. Also, no vaccine for use in humans is yet approved by the regulatory bodies. The chief drug that is used in the symptomatic treatment of Ebola virus are: Belladona, Aconite, Bryonia. (c) 2019 iGlobal Research and Publishing Foundation. All rights reserved.
\end{abstract}

Cite this article as: Kaur, P.; Sodhi, R.; Kamboj, A.; Babu, A. Ebola: Treatment by Herbal Remedies. Indo Global J. Pharm. Sci., 2019; 9(2Suppl.): 119. DOI: http://doi.org/10.35652/IGJPS.2019.92S17.

Indo Global Journal of Pharmaceutical Sciences( ISSN 2249 1023; CODEN- IGJPAI; NLM ID: 101610675) indexed and abstracted in CrossRef (DOI Enabling), UGC CARE Journal List, EMBASE(Elsevier), National Library of Medicine (NLM) Catalog, ResearchGate, Publons, CAS (ACS), Index Copernicus, Google Scholar and many more. For further details, visit http://iglobaljournal.com

This is a special issue as an outcome of 'RAPSCON-2019' sponsored by APTI and organized by Sri Sai College of Pharmacy, Manawala, Amritsar, Punjab, India. Relaxation offered in journal format. 